\title{
Immunomodulation and interferon gamma gene expression in sutchi cat fish, Pangasianodon hypophthalmus: effect of dietary fucoidan rich seaweed extract (FRSE) on pre and post challenge period
}

\author{
Dhanasekaran Linga Prabu, Narottam P Sahu, Asim K Pal, Subrata Dasgupta \& Ashalaxmi \\ Narendra \\ Department of Fish Nutrition, Biochemistry and Physiology, Central Institute of Fisheries Education, Mumbai, India
}

Correspondence: D L Prabu, Department of Fish Nutrition, Biochemistry and Physiology, Central Institute of Fisheries Education, Mumbai, India. E-mail: growelprabu@gmail.com

\begin{abstract}
A 45-days feeding trial was conducted to study the immunomodulatory effect and interferon gamma gene expression of dietary fucoidan rich seaweed extract (FRSE) from Sargassum wightii on Pangasianodon hypophthalmus fingerlings. One hundred and eighty fingerlings were distributed into six experimental groups in triplicates. Each group was stocked with 10 fish and fed to satiation with iso-nitrogenous (34.96 $\pm 0.09-35.18 \pm 0.03 \mathrm{CP} \%)$ and iso-caloric $(368.65 \pm 0.86-375.09 \pm 0.26 \mathrm{Kcal} / 100 \mathrm{~g})$ purified diets containing either 0\% FRSE (control), 1\% FRSE $\left(\mathrm{TF}_{1}\right), 2 \%$ FRSE $\left(\mathrm{TF}_{2}\right), 3 \%$ FRSE $\left(\mathrm{TF}_{3}\right), 3 \%$ seaweed powder $\left(\mathrm{TS}_{3}\right)$ or $6 \%$ seaweed powder $\left(\mathrm{TS}_{6}\right)$ in the feed. After feeding trial the experimental fish were challenged with Aeromonas hydrophila. Immunological parameters like respiratory burst activity, lysozyme activity, phagocytic activity and total leukocyte count (TLC) were increased with the increasing level of dietary FRSE, whereas serum Albumin/ Globulin $(\mathrm{A} / \mathrm{G})$ ratio and blood glucose level exhibited decreasing trend $(P<0.05)$. Increased TLC, blood glucose level, respiratory burst activity, serum A/G ratio, lysozyme and phagocytic activities were recorded during the post-challenge period. Maximum expression of interferon gamma (IFN- $\gamma$ ) gene was recorded in FRSE fed groups than the control group both in pre and post challenge condition. After challenged with $A$. hydrophila the highest survival was observed in $\mathrm{TF}_{2}$ and $\mathrm{TF}_{3}$ groups whereas lowest survival was observed in the control group. Hence,
\end{abstract}

dietary supplementation of FRSE at an optimum level of $2 \%$ reduced the stress and improved the immune status of $P$. hypophthalmus fingerlings.

Keywords: fucoidan rich seaweed extract, interferon gamma gene, pre and post challenge, immunomodulatory effect, Sargassum wightii, Pangasianodon hypophthalmus

\section{Introduction}

Over the past three decades, aquaculture has developed to become the fastest growing food producing sector in the world. Worldwide aquaculture production is expanding day by day, for which there is an increasing interest in fish health. Hence, immunomodulation has been proposed as a potential method to protect the cultured fish from infectious pathogens by increasing their innate immune system (Aoki 1992).

Pangasianodon hypophthalmus is the most popular fish among the fish farmers in South East Asian countries because of its fast growth rate and high stocking density. The intensive farming of pangasius led to a lot of disease problems because of highly endured stress and loss of immunity. This leads the fish more susceptible to bacterial diseases like haemorrhagic septicaemia or red disease which is caused by the bacteria, Aeromonas hydrophila. To safe guard the fish from the diseases and to increase the aquaculture production feeding of immunostimulants are ideal protective measures, 
which improve their non-specific defense mechanism.

Many natural compounds especially nutraceuticals or phytochemicals have already used in animal feeds as immune-modulators, but their use in aquaculture is scanty. In this context, fucoidan, a polysaccharide which contains substantial percentages of L-fucose and sulphate easter groups, mainly derived from brown seaweeds, has shown promising result as an immune-stimulant. Fucoidan, being an antioxidant has the potential to scavenge the free radicals formed in the body of animal at the time of endured stress (Zhang, Yu, Zhou, Li \& Xu 2003). Fucoidan has the property to stimulate the innate immune mechanism by the activation of macrophages and natural killer cells through different receptors and ultimately connect the adaptive immune defense mechanism by the cytokines which in turn stimulate the leucocytes to its enrichment and arrived at the site of infection. Fucoidan isolated from Laminaria japonica and its fractions have antioxidant activities, which are related to their immune-modulatory activities (Ren-na, Jian-ming, Chun-nian, Wei-wei \& Qi 2008).

The immune-enhancing properties of fucoidan involve its ability to stimulate natural killer cells, which play an important part in the immune response by destroying cells infected with viruses (Maruyama, Tamauchi, Iizuka \& Nakano 2006). Fucoidan can induce the production of interleukin-1 (IL-1) and interferon- $\gamma$ (IFN- $\gamma$ ) in-vitro, enhance the functions of T- lymphocyte, B-cell, macrophages and natural killer cells (NK cell) and promote the primary antibody response to sheep red blood cell (SRBC) in-vivo (Yang, Sun \& Xu 1995). Fucoidan from Fucus vesiculosus has immune-stimulating and maturing effects on dendritic cells (DCs), which are powerful antigen-presenting cells, via a pathway involving at least

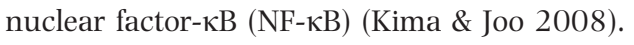

The aqueous extracts of some of the brown seaweeds induced an increase in the respiratory burst activity of turbot phagocytes, suggesting that most of the immune-stimulatory capacity associated with polysaccharides (Castro, Zarra \& Lamas 2004). The oral administration of Sargassum fusiforme polysaccharide extracts at an optimal level of $0.5 \%$ and $1.0 \%$ for 14 days effectively improved vibriosis resistance and enhanced immune activity in Fenneropenaeus chinensis (Huang, Zhou \& Zhang 2006). The oral administration of Sargassum polycystum crude fucoidan (CF) inhibited the growth of Vibrio harveyi, Staphylococcus aureus and Escherichia coli at minimal inhibition concentrations (Chotigeat, Tongsupa, Supamataya \& Phongdara 2004). The juveniles of Marsupenaeus japonicas fed with diets supplemented with Undaria pinnatifida fucoidan had potential serum antibacterial effect against Vibrio harveyi than the control group (Traifalgar, Kira, Tung, Michael, Laining, Yokoyama, Ishikawa \& Koshio 2010).

In shrimp, the antiviral activity of fucoidan against WSSV was reported from different brown seaweeds by numerous workers (Takahashi, Uehara, Watanabe, Okumura, Yamashita, Omura, Yomo, Kawano, Kanemitsu, Narasaka, Suzuki \& Itami 1998; Chotigeat et al. 2004; Cruz-Suárez, Hernández, Porchas-Cornejo, Coronado-Molina, Linné-Unzueta-Bustamante, Nieto-López, Tapia-Salazar \& Ricque-Marie 2007; Immanuel, Sivagnanavelmurugan, Balasubramanian \& Palavesam 2010). Although promising effect of dietary fucoidan has been reported in shrimp, but reports on the effect of fucoidan in fish is very limited.

Fucoidan is widely available from various cheap resource brown seaweeds. Hence, fucoidan has been one of focussed area of research to develop the functional foods or nutraceuticals for both in human and animal use. In this context, present work was designed to study the effects of dietary supplementation of fucoidan rich seaweed extract (FRSE), prepared from $S$. wightii on immunological responses of $P$. hypophthalmus challenged with $A$. hydrophila.

\section{Material and methods}

\section{Seaweed collection and fucoidan rich seaweed extract (FRSE) preparation}

Indian brown seaweed, $S$. wightii samples were collected during morning hours in the month of September from Mandapam, Ramanathapuram district of Tamil Nadu, India. Freshly collected matured, disease free and healthy $S$. wightii were thoroughly washed in freshwater to remove dirt and any other extraneous materials adhering to them and shade dried for about 3 days followed by pulverized to fine powder.

The dried seaweed powder of $100 \mathrm{~g}$ was taken into an appropriate sized vessel to which $1 \mathrm{~L}$ of $85 \%$ ethanol was added, followed by stirring with magnetic stirrer for $12 \mathrm{~h}$. The alcohol was decanted 
and the wet slurry was washed with acetone, centrifuged at $29030 \mathrm{~g}$ for $10 \mathrm{~min}$ and the supernatant was decanted. The residual seaweed was dried at room temperature to remove the acetone completely. Furthermore, the dried residue was added with $700 \mathrm{~mL}$ distilled water and stirred for $1 \mathrm{~h}$ at $65^{\circ} \mathrm{C}$. The hot mixture was filtered and the supernatant was collected. The pre-extracted residue was re-extracted with $350 \mathrm{~mL}$ of distilled water as done before and filtered again. Both extracts were mixed together and centrifuged at $29030 \mathrm{~g}$ for $10 \mathrm{~min}$. The supernatant was collected and $1 \% \mathrm{CaCl}_{2}$ was added by vigorous mixing, which was stored at $4^{\circ} \mathrm{C}$ for overnight to precipitate the alginic acid as a calcium salt of alginate. Next day morning, precipitated mixture was centrifuged and the brown colour pellet was removed by leaving the same colour aliquot. This supernatant was fucoidan rich seaweed extract (FRSE).

\section{Quantification of FRSE}

The fucoidan rich seaweed sample was dialysed and used for quantification. L-fucose content was analysed (Dubois, Gilles, Hamilton, Rebers \& Smith 1956). Two millilitre of FRSE was pipetted into calorimetric tube and $50 \mu \mathrm{L}$ of $80 \%$ phenol was added to it. Then $5 \mathrm{~mL}$ of concentrated sulphuric acid was added rapidly, the stream of acid was directed against the liquid surface rather than against the side of the test tube to obtain good mixing. The tube was allowed to stand for $10 \mathrm{~min}$. Then, they were shaken and placed for $20 \mathrm{~min}$ in water bath at $37^{\circ} \mathrm{C}$. The absorbance of the characteristic yellow-orange solution was measured at $480 \mathrm{~nm}$. From the L-fucose content the fucoidan yield was calculated empirically that $1 \mu \mathrm{g}$ of fucoidan is equivalent to $1.75 \times$ fucose $(\mu \mathrm{g})$ (Doner \& Whistler 1973; Choosawad, Leggat, Dechsukhum, Phongdara \& Chotigeat 2005).

\section{Experimental diets}

Purified ingredients such as casein (fat free), gelatin, dextrin, starch, cellulose, carboxy methyl cellulose (Himedia Chemical, Mumbai, Maharastra, India), cod liver oil, sunflower oil, BHT, vitamin and mineral mixture (PREEMIX PLUS, Mumbai, India) and choline chloride were used for feed formulation (Table 1). Six experimental diets with the same proximate composition with the crude protein and lipid levels at $35 \%$ and $8 \%$, respectively, were prepared which contained graded levels of fucoidan rich seaweed extract (FRSE)/seaweed powder. The diets having graded levels of FRSE/seaweed powder were: $0 \%$ FRSE (control), 1\% FRSE (TF $\left.{ }_{1}\right), 2 \%$ FRSE $\left(\mathrm{TF}_{2}\right), 3 \%$ FRSE $\left(\mathrm{TF}_{3}\right), 3 \%$ seaweed powder $\left(\mathrm{TS}_{3}\right)$ and $6 \%$ seaweed powder $\left(\mathrm{TS}_{6}\right)$. All the ingredients were thoroughly mixed with required amount of water to make the dough except the oil, BHT and vitaminmineral mix. Then, the dough was steam cooked for $10 \mathrm{~min}$ in an autoclave. After cooling BHT, oil and vitamin-mineral mix were mixed thoroughly to get even distribution of vitamin and mineral in the dough. Then, the dough was pressed through a hand pelletizer of $2 \mathrm{~mm}$ diameter to prepare pellet, which were dried at $40^{\circ} \mathrm{C}$ in hot air oven and finally packed and stored in refrigerator at $4^{\circ} \mathrm{C}$ until use.

\section{Experimental animals}

Fingerlings of iridescent shark or sutchi catfish, Pangasianodon hypophthalmus with a weight of 10.0-15.0 g were procured from Kakdwip Research Centre of Central Institute of Brackish water Aquaculture, West Bengal, India. The fish were air lifted with sufficient aeration to the wet laboratory, Central Institute of Fisheries Education. They were carefully transferred to a circular tank (1000 L) with black background supplied with vigorous aeration. The fish left undisturbed the whole night. To ameliorate the handling stress, the fish were given a mild salt treatment $(2.0 \%)$ for $2 \mathrm{~min}$ in the next day morning and mild dose of $\mathrm{KMnO}_{4}$ dip treatment. Vitamin $\mathrm{C}\left(2 \mathrm{mg} \mathrm{L}^{-1}\right)$ was also given to the fish as bath treatment. The stock was acclimatized under aerated conditions with a purified diet containing 35\% crude protein for 1 month.

\section{Fish rearing}

The experiment was conducted for a period of 45 days in 18 black background plastic rectangular tubs $(80 \times 57 \times 42 \mathrm{~cm}, 150 \mathrm{~L}$ capacity) covered with perforated lids. The tubs were initially washed and filled with $\mathrm{KMnO}_{4}$ solution $\left(4 \mathrm{mg} \mathrm{L}^{-1}\right)$ and were left overnight and washed with clean water in the next day morning before stocking with experimental fish. Totally one hundred and eighty fingerlings with initial weight ranging from 17.0 to 20.0 g were randomly distributed in six experimental groups with each of three replicates which following a completely randomized design. The total volume of the water in each tub was maintained 
Table 1 Composition of experimental diets (g \%)

\begin{tabular}{|c|c|c|c|c|c|c|}
\hline Ingredients & Control & $\mathrm{TF}_{1}$ & $\mathrm{TF}_{2}$ & $\mathrm{TF}_{3}$ & $\mathrm{TS}_{3}$ & $\mathrm{TS}_{6}$ \\
\hline Casein & 33.00 & 33.00 & 33.00 & 33.00 & 33.00 & 33.00 \\
\hline Gelatin & 7.25 & 7.25 & 7.25 & 7.25 & 7.25 & 7.25 \\
\hline Dextrin & 16.75 & 16.75 & 16.75 & 16.75 & 16.75 & 16.75 \\
\hline Starch soluble & 19.50 & 19.50 & 19.50 & 19.50 & 19.50 & 19.50 \\
\hline Cellulose & 11.00 & 10.00 & 9.00 & 8.00 & 8.00 & 5.00 \\
\hline Cod liver oil & 4.00 & 4.00 & 4.00 & 4.00 & 4.00 & 4.00 \\
\hline Sunflower oil & 4.00 & 4.00 & 4.00 & 4.00 & 4.00 & 4.00 \\
\hline Vitamin mineral & 2.00 & 2.00 & 2.00 & 2.00 & 2.00 & 2.00 \\
\hline $\mathrm{CMC}$ & 2.00 & 2.00 & 2.00 & 2.00 & 2.00 & 2.00 \\
\hline Choline chloride & 0.40 & 0.40 & 0.40 & 0.40 & 0.40 & 0.40 \\
\hline BHT & 0.10 & 0.10 & 0.10 & 0.10 & 0.10 & 0.10 \\
\hline $\begin{array}{l}\text { FRSE/ } \\
\text { Seaweed powder }\end{array}$ & 0.00 & 1.00 & 2.00 & 3.00 & 3.00 & 6.00 \\
\hline Total & 100 & 100 & 100 & 100 & 100 & 100 \\
\hline
\end{tabular}

Composition of vitamin mineral mix (PREEMIX PLUS) (quantity/2.5 kg). Vitamin A, 5500000 IU; Vitamin D3, 1100000 IU; Vitamin B2, 2000 mg; Vitamin E, 750 mg; Vitamin K, 1000 mg; Vitamin B6, 1000 mg; Vitamin B12, 6 mcg; Calcium Pantothenate, $2500 \mathrm{mg}$; Nicotinamide, $10 \mathrm{~g}$; Choline Chloride, $150 \mathrm{~g}$; Mn, $27000 \mathrm{mg} ; \mathrm{I}, 1000 \mathrm{mg}$; Fe, $7500 \mathrm{mg}$; Zn, $5000 \mathrm{mg}$; Cu, $2000 \mathrm{mg}$; Co, 450 L-lysine, $10 \mathrm{~g}$; DL-Methionine, $10 \mathrm{~g}$; Selenium, 50 ppm.

equally and continuous aeration was provided in all the tubs throughout the experimental period. The fish were fed to satiation for 45 days in two frequencies daily one at $10.00 \mathrm{~h}$ in the morning and other at $18.00 \mathrm{~h}$ in the evening under normal light regime. The leftover feed and faecal matter were siphoned out in everyday morning with about 30$50 \%$ of water exchange. Water quality parameters viz. temperature, $\mathrm{pH}$, dissolved oxygen, free carbon dioxide, total hardness, ammonia, nitrite and nitrate levels were recorded during the experimental period.

\section{Growth parameters and survival rate}

Sampling for growth was done at every 15 days to assess the body weight of the fish. Fish were starved overnight before taking the weight. The weight was taken in an electronic balance. The growth performance was assessed using the following formulae:

$$
\begin{aligned}
& \text { Weight gain }(\%) \\
& =\frac{\text { Final weight }- \text { Initial weight }}{\text { Initial weight }} \times 100
\end{aligned}
$$

$$
\begin{aligned}
& \text { Specific growth rate }(\mathrm{SGR}) \% \\
& =\frac{\log _{e} \text { final weight }-\log _{e} \text { initial weight }}{\text { Number of days }} \\
& \quad \times 100
\end{aligned}
$$

$$
\begin{aligned}
& \text { Feed conversion ratio (FCR) } \\
& =\frac{\text { Feed consumption (dry weight) }}{\text { Body weight gain (wet weight) }} \\
& \text { Protein efficiency ratio (PER) } \\
& =\frac{\text { Net weight gain (wet weight) }}{\text { Protein fed }}
\end{aligned}
$$

At the end of the experiment, all the experimental tubs were dewatered and the number of the experimental animals in each tub was counted and the survival rate (\%) was calculated by the following formula:

$$
\begin{aligned}
& \text { Survival rate }(\%) \\
& =\frac{\text { Total number of fish harvested }}{\text { Total number of fish stocked }} \times 100
\end{aligned}
$$

\section{Sampling}

At the end of 45 days of feeding trial, the sampling was carried out for the analysis of the respiratory burst activity, phagocytic activity, blood glucose level and other blood parameters such as haemoglobin content, total erythrocytes, leukocyte count and haematocrit value. There were two fish from each replicate anaesthetized using clove oil (50 $\mu \mathrm{L} \mathrm{L}^{-1}$ ) and blood was drawn from the caudal vein (Vena caudalis) using a tuberculin syringe rinsed with 2.7\% EDTA solution (an anti-coagulant) to prevent blood clotting. The blood samples from 
the fish of the same replicate were pooled in an eppendorf tube containing a pinch of EDTA powder, shaken mildly to prevent haemolysis of blood and then kept at $4^{\circ} \mathrm{C}$ until use. For serum collection another six fish from each treatment was anaesthetized and blood was collected without anticoagulant treatment, allowed to clot for $3 \mathrm{~h}$ followed by serum was collected with micropipette and stored at $-20^{\circ} \mathrm{C}$ until use.

\section{Blood glucose}

Blood glucose was estimated by the modified method of Nelson and Somogyi (Oser 1944). One hundred micro litre of blood sample was de-proteinized by mixing with $4.75 \mathrm{~mL}$ of $0.174 \mathrm{M}$ zinc sulphate and $4.75 \mathrm{~mL}$ of $0.142 \mathrm{M}$ barium hydroxide. The solution was mixed vigorously and filtered through a filter paper and the filtrate was collected in a dry test tube. Then $1 \mathrm{~mL}$ of alkaline copper sulphate solution was added in to $0.5 \mathrm{~mL}$ of filtrate. The test tubes were placed in a boiling water bath for $20 \mathrm{~min}$. Then cooled to room temperature and $1 \mathrm{~mL}$ arseno molybdate reagent was added. The absorbance was recorded at $540 \mathrm{~nm}$ against blank.

\section{Haematological parameters}

The determination of haemoglobin was done by cyanmethaemoglobin method using Drabkin's fluid (Qualigens Fine Chemicals, Mumbai, India). Five millilitres of Drabkin's working solution was taken in a test tube followed by $20 \mu \mathrm{L}$ of blood was added to it and the absorbance was measured using a spectrophotometer (MERCK-Thermo Electron, Madison, WI, USA) at a wavelength of $540 \mathrm{~nm}$. The total erythrocyte and leucocyte were counted in a haemocytometer by taking $3980 \mathrm{~mL}$ of erythrocyte and leucocyte diluting fluids (Qualigens), respectively, in a separate clean glass vial and $20 \mu \mathrm{L}$ of blood was added to it. Then the solution was mixed thoroughly to suspend the cells uniformly in the solution and the cells were counted in haemocytometer to calculate the total number of erythrocytes and leucocytes per millilitre of the blood sample by the following formula:

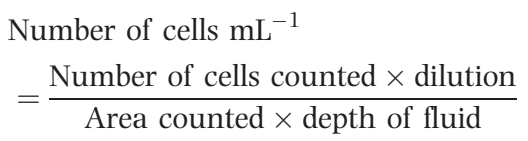

The packed cell volume (PCV) was analysed by drawing non-dotted blood by capillary action into microhaematocrit tubes. The microhaematocrit tubes were sealed at one end with synthetic sealant. The sealed tubes were centrifuged in a microhaematocrit centrifuge for $5 \mathrm{~min}$ at $12300 \mathrm{~g}$ measured using microhaematocrit reader. Then PCV was expressed as PCV percentage.

\section{Respiratory burst activity}

Nitroblue tetrazolium (NBT) assay following the method of Secombes (1990) subsequently modified by Stasiack and Bauman (1996) was used for the estimation of respiratory burst activity of the phagocytes. The wells of 'flat bottom' microtitre plates were loaded with $50 \mu \mathrm{L}$ of blood samples and incubated at $37^{\circ} \mathrm{C}$ for $1 \mathrm{~h}$ to allow adhesion of cells. The supernatant was decanted and the wells were washed thrice with PBS. After washing, $50 \mu \mathrm{L}$ of $0.2 \%$ NBT was loaded in the wells and incubated for $1 \mathrm{~h}$. Then the cells were fixed with $100 \%$ methanol for 2-3 min and again washed thrice by using 70\% methanol. The plates were air-dried for $5 \mathrm{~min}$. After air drying, $60 \mu \mathrm{L}$ of $2 \mathrm{~N}$ potassium hydroxide and $70 \mu \mathrm{L}$ of dimethyl sulphoxide were subsequently added in to all the wells to dissolve the formazon blue precipitate formed. Finally the OD of turquoise blue coloured solution was recorded in an ELISA reader at $540 \mathrm{~nm}$.

\section{Serum total protein, albumin and globulin}

Serum total protein was estimated by the Biuret method (Reinhold 1953) using a Innoline Total protein kit. Albumin was estimated by the bromocresol green binding method (Doumas \& Biggs 1972) using Innoline albumin kit. The absorbance of the standard and test was measured against a blank in a spectrophotometer at $550 \mathrm{~nm}$ and $578 \mathrm{~nm}$, respectively, for total serum protein and albumin. Globulin values were obtained by subtracting the albumin values from the total serum protein values. The albumin/globulin ratio (A/G ratio) was calculated by dividing albumin values by globulin values.

\section{Serum lysozyme activity}

Serum lysozyme activity was carried out by using Anderson-Siwicki method (Anderson \& Siwicki 
1995). In the 96 well $U$ bottom microtitre plate $150 \mu \mathrm{L}$ of Micrococcus luteus suspension in phosphate buffer $\left(\mathrm{A}_{450}=0.5-0.7\right)$ was taken and $50 \mu \mathrm{L}$ of serum samples were added into it. The contents of microtitre plate were mixed thoroughly and immediately OD value was taken at $450 \mathrm{~nm}$ in ELISA reader. Then the plate was incubated at $25^{\circ} \mathrm{C}$ for $1 \mathrm{~h}$ and final OD was taken. This absorbance was compared with standard lysozyme of known activity by the same procedure. A unit of lysozyme activity was defined as the amount of sample causing a reduction in absorbance of 0.001 per minute and the lysozyme activity was expressed as $\mathrm{U} \mathrm{min}^{-1} \mathrm{mg}^{-1}$ protein of serum.

\section{Phagocytic activity and phagocytic index}

The phagocytic cells were detected with Staphylococcus aureus (Bangalore Genei, Hyderabad, India) by the method of Anderson - Siwicki (Anderson \& Siwicki 1995). One hundred micro litres of blood sample was placed in the wells of microtitre plate followed by $100 \mu \mathrm{L}$ of $S$. aureus $1 \times 10^{7}$ cells suspended in phosphate buffered saline $(\mathrm{pH} 7.2)$ was added and mixed thoroughly. This mixture was incubated for $20 \mathrm{~min}$ at room temperature. Then, $5 \mu \mathrm{L}$ of this mixture was taken on to a clean glass slide and a smear was prepared. The smear was air dried for $5 \mathrm{~min}$. After air drying, fixed with 95\% ethanol for $5 \mathrm{~min}$ and again air dried. Then the smear was stained with Giemsa stain for $10 \mathrm{~min}$. The sum of 100 neutrophils and monocytes from each smear were observed under the light microscope and the number of phagocytising cells and bacteria engulfed by the phagocyte were counted. The phagocytic activity defined as the number of phagocytising cells divided by the total number of phagocytes counted. The phagocytic index is expressed as the total number of bacteria engulfed by the phagocytes, divided by the total number of phagocytes containing engulfed bacteria.

\section{Pathogenic bacteria}

The pathogenic bacteria, Aeromonas hydrophila was procured from the Aquatic Animal Health and Management Division, Central Institute of fisheries Education (CIFE), Mumbai. A. hydrophila was grown on nutrient broth (Himedia, Mumbai, India) for $24 \mathrm{~h}$ at $28^{\circ} \mathrm{C}$. The culture broth was centrifuged at $3000 \mathrm{~g}$ for $10 \mathrm{~min}$. The supernatant was decanted and the pellet was re-suspended in sterile phosphate buffer saline ( $\mathrm{pH} 7.4)$. The OD of the solution was adjusted to 0.5 at $456 \mathrm{~nm}$ by serial dilution to obtain the final bacterial cell concentration of $1.8 \times 10^{7} \mathrm{CFU} \mathrm{mL} \mathrm{L}{ }^{-1}$ which is used for challenge study (Misra, Sahu, Pal, Xavier, Kumar \& Mukherjee 2006; Christybapita, Divyagnaneswari \& Michael 2007; Mohamad \& Abasali 2010).

\section{Challenge study}

Five days after the initial sampling, five fish from each replicate of the experimental groups were injected intraperitoneally with $200 \mu \mathrm{L}$ of bacterial suspension with bacterial cell concentration of $1.8 \times 10^{7} \mathrm{CFU} \mathrm{mL}{ }^{-1}$. Mortality was observed for 10 days in all the experimental groups. Post challenge sampling of the surviving fish were carried out on the 10th day for post challenge analysis. A. hydrophila was confirmed from the dead fish by isolating it from the dead fish. Survival was calculated using the following formula:

$$
\begin{aligned}
& \text { Relative \% of survival } \\
& =\frac{\text { No of fish survived after challenge }}{\text { No of fish injected }} \\
& \quad \times 100
\end{aligned}
$$

\section{Partial sequencing of interferon gamma 2 gene from P. hypophthalmus}

The cloning for partial sequencing of interferon gamma 2 gene was done from spleen and head kidney samples collected from $P$. hypophthalmus. Total RNA was extracted using Trizol reagent (Invitrogen Bioservices India, Bangalore, Karnataka, India) following standard protocol. The cDNA was synthesized using the first strand cDNA synthesis kit (Fermentas, Hanover, MA, USA) following manufacturer's instructions. The PCR reaction was performed with the following degenerate interferon- $\gamma 2$ forward (CCTCCCGAAGAACATCAAGG) and reverse (TTAGCTTGACGTCGTCTCC) primers and $\beta$-actin forward (GACTTCGAGCAGGAGATGG) and reverse (CAAGAAGGATGGCTGGAACA) primers. PCR amplification was carried out by normal cyclic conditions with $50^{\circ} \mathrm{C}$ annealing temperature in the Peltier thermal Cycler (Biorad MJ Research, Gurgaon, Haryana, India). The resulting PCR product of the expected size was gel excised and isolated using the QIAquick gel extraction kit (Qiagen, Hilden, Germany), cloned in a bacterial vector using the InsTA 
PCR cloning kit (Fermentas) and transformed in Escherichia coli competent cells following the manufacturer's instructions. White colonies were selected from X-Gal/IPTG ampicillin LB agar plates and grown in LB/ampicillin liquid media and plasmids were further purified using the QIAprep spin miniprep kit (Qiagen). The cloned products were sequenced using universal primers M13 by ABI prism 377automatic sequencer (Bangalore Genei). The sequence was analysed using BLAST (Basic Local Alignment Search Tool) software in the NCBI (National Centre for Biotechnology Information) GenBank nucleotide database for finding homology with other sequences and submitted to NCBI GenBank.

\section{Expression using semi-quantitative RT-PCR}

The semi-quantitative analysis of $P$. hypophthalmus interferon- $\gamma$ 2a was done after 45 days of FRSE diet feeding and again after artificial infection with $A$. hydrophila was studied by RT-PCR analysis. The primer sequences used in RT-PCR analysis are PHIFN_F (GGCTCAGGATGAAAAGGTGA) and PHIFN_R (CTCTGGGTCAGTGGGTCATT). The both forward (PHIFN_F) and the reverse (PHIFN_R) primers are having same base pair length i.e. 20 numbers. The relative changes in intensity of bands were measured using Gel-Pro Software Version 4.5.

\section{Statistical analysis}

The effect of FRSE on the immunomodulation of $P$. hypophthalmus was done with one way ANova. The mean values for pre- and post-challenge parameters were compared by Student's t-test. Duncan's multiple range test was used to determine the significant differences between the treatment means. All statistical analysis was done using the software package spss (version 16).

\section{Results}

\section{Quantification of fucoidan rich seaweed extract (FRSE)}

The dialysed fucoidan rich seaweed extract was quantified by measuring the L-fucose content and the L-fucose content was multiplied by the factor 1.75. The L-fucose content was determined by colorimetric method and the quantity of L-fucose was $31.61 \mathrm{mg} \mathrm{g}^{-1}$ dried seaweed powder. Hence, the fucoidan content was $55 \mathrm{mg} \mathrm{g}^{-1}$ or $5.5 \mathrm{~g} / 100 \mathrm{~g}$ dried seaweed powder.

\section{Physico-chemical parameters of water}

The physico-chemical parameters of water such as temperature $\left({ }^{\circ} \mathrm{C}\right), \mathrm{pH}$, dissolved oxygen $\left(\mathrm{mg} \mathrm{L}^{-1}\right)$, free carbon dioxide $\left(\mathrm{mg} \mathrm{L}^{-1}\right)$, total hardness $\left(\mathrm{mg} \mathrm{L}^{-1}\right)$, ammonia $\left(\mathrm{mg} \mathrm{L}^{-1}\right)$, Nitrite $-\mathrm{N}$ $\left(m g L^{-1}\right)$, Nitrate $-\mathrm{N}\left(\mathrm{mg} \mathrm{L}^{-1}\right)$ were recorded during the experiment and the range of physicochemical parameter values of all the treatments are presented in Table 2.

\section{Growth parameters and survival rate}

The growth parameters such as weight gain percentage, specific growth rate (SGR), feed conversion ratio (FCR) and protein efficiency ratio (PER) of the experimental groups were listed in the Table 3. The weight gain percentage was found to be significantly different $(P<0.001)$ among the various treatment groups. The highest SGR was found in $\mathrm{TF}_{3}$ which was significantly higher $(P<0.001)$ than the all other groups. The FCR of different experimental groups varied significantly $(P<0.001)$. The best $\mathrm{FCR}$ was found in $\mathrm{TF}_{3}$ group. And the same way the highest PER was found in $\mathrm{TF}_{3}$ treatment group. The survival rates of the fish in the different experimental groups are given in the Table 3. There was no mortality observed in the $\mathrm{TF}_{1}, \mathrm{TF}_{2}, \mathrm{TF}_{3}$ and $\mathrm{TS}_{6}$ groups.

\section{Blood glucose}

Control group showed higher glucose level than the FRSE diet fed treatment groups during pre-challenge condition. However, there was no significant variation among the treatment groups $(P>0.05)$. Similarly control group in post challenge condition showed highest value and lowest value was recorded in $\mathrm{TF}_{3}, \mathrm{TF}_{2}$ and $\mathrm{TS}_{6}$ groups (Fig. 1). There was no significant difference $(P>0.05)$ between pre challenge and post challenge blood glucose level of different treatments except control group $(P<0.05)$.

Blood haemoglobin, Total erythrocyte count (TEC), Total leucocyte count (TLC) and Haematocrit value

Significant variation $(P<0.001)$ in both pre and post challenge haematological parameters were 
Table 2 Physico-chemical parameters of water during the experimental period of 45 days for different experimental groups

\begin{tabular}{lllllllll}
\hline Treatments & $\begin{array}{l}\text { Temperature } \\
\left({ }^{\circ} \mathbf{C}\right)\end{array}$ & $\mathbf{p H}$ & $\begin{array}{l}\text { Dissolved } \\
\text { oxygen }(\mathbf{p p m})\end{array}$ & $\begin{array}{l}\text { Free } \mathrm{CO}_{2} \\
(\mathbf{p p m})\end{array}$ & $\begin{array}{l}\text { Hardness } \\
(\mathbf{p p m})\end{array}$ & $\begin{array}{l}\text { Ammonia } \\
(\mathbf{p p m})\end{array}$ & Nitrite (ppm) & $\begin{array}{l}\text { Nitrate } \\
(\mathbf{p p m})\end{array}$ \\
\hline Control & $25.2-27.4$ & $7.6-8.2$ & $6.0-6.5$ & $\mathrm{ND}$ & $230-241$ & $0.06-0.08$ & $0.085-0.088$ & $1.0-1.1$ \\
$\mathrm{TF}_{1}$ & $25.6-28.4$ & $7.7-8.0$ & $6.1-6.8$ & $\mathrm{ND}$ & $232-242$ & $0.06-0.01$ & $0.086-0.087$ & $0.98-0.99$ \\
$\mathrm{TF}_{2}$ & $25.2-27.8$ & $7.8-8.1$ & $6.2-6.6$ & $\mathrm{ND}$ & $236-241$ & $0.05-0.07$ & $0.084-0.085$ & $1.05-1.2$ \\
$\mathrm{TF}_{3}$ & $25.4-27.5$ & $7.5-8.4$ & $6.1-6.5$ & $\mathrm{ND}$ & $224-248$ & $0.07-0.09$ & $0.088-0.089$ & $0.89-1.0$ \\
$\mathrm{TS}_{3}$ & $25.8-27.9$ & $7.7-8.2$ & $5.8-6.4$ & $\mathrm{ND}$ & $222-252$ & $0.03-0.07$ & $0.078-0.087$ & $0.76-0.94$ \\
$\mathrm{TS}_{6}$ & $25.6-28.2$ & $7.8-8.2$ & $5.7-6.6$ & $\mathrm{ND}$ & $220-260$ & $0.05-0.09$ & $0.081-0.083$ & $0.79-0.82$ \\
\hline
\end{tabular}

$\mathrm{ND}$, not detected.

Table 3 Growth parameters and survival rate of different experimental groups fed different experimental diets at the end of the experiment

\begin{tabular}{lllllc}
\hline Treatments & Wt. gain (\%) & SGR & FCR & PER & Survival rate (\%) \\
\hline Control & $40.72^{\mathrm{a}} \pm 1.36$ & $0.76 \mathrm{c}^{\mathrm{a}} \pm 0.021$ & $3.57^{\mathrm{c}} \pm 0.116$ & $0.81^{\mathrm{a}} \pm 0.026$ & $96.67 \pm 3.33$ \\
$\mathrm{TF}_{1}$ & $52.36^{\mathrm{b}} \pm 1.27$ & $0.94^{\mathrm{b}} \pm 0.018$ & $2.86^{\mathrm{b}} \pm 0.063$ & $1.03^{\mathrm{b}} \pm 0.023$ & $100.00 \pm 0$ \\
$\mathrm{TF}_{2}$ & $54.85^{\mathrm{b}} \pm 0.88$ & $0.97^{\mathrm{b}} \pm 0.012$ & $2.75^{\mathrm{b}} \pm 0.035$ & $1.06^{\mathrm{b}} \pm 0.013$ & $100.00 \pm 0$ \\
$\mathrm{TF}_{3}$ & $61.84^{\mathrm{c}} \pm 1.37$ & $1.07 \pm 0.018$ & $2.47^{\mathrm{a}} \pm 0.060$ & $1.19^{\mathrm{c}} \pm 0.029$ & $100.00 \pm 0$ \\
$\mathrm{TS}_{3}$ & $50.65^{\mathrm{b}} \pm 1.16$ & $0.91^{\mathrm{b}} \pm 0.017$ & $2.93^{\mathrm{b}} \pm 0.070$ & $1.00^{\mathrm{b}} \pm 0.023$ & $96.67 \pm 3.33$ \\
$\mathrm{TS}_{6}$ & $51.93^{\mathrm{b}} \pm 2.36$ & $0.93^{\mathrm{b}} \pm 0.034$ & $2.89^{\mathrm{b}} \pm 0.119$ & $1.01^{\mathrm{b}} \pm 0.043$ & $100.00 \pm 0$ \\
$P$ value & 0.001 & 0.001 & 0.001 & 0.001 & 0.571 \\
\hline
\end{tabular}

Mean values in the same column with different superscript differ significantly $(P<0.05)$. Data were expressed as Mean \pm SE $n=3$ SGR, specific growth rate; FCR, feed conversion ratio; PER, protein efficiency ratio.

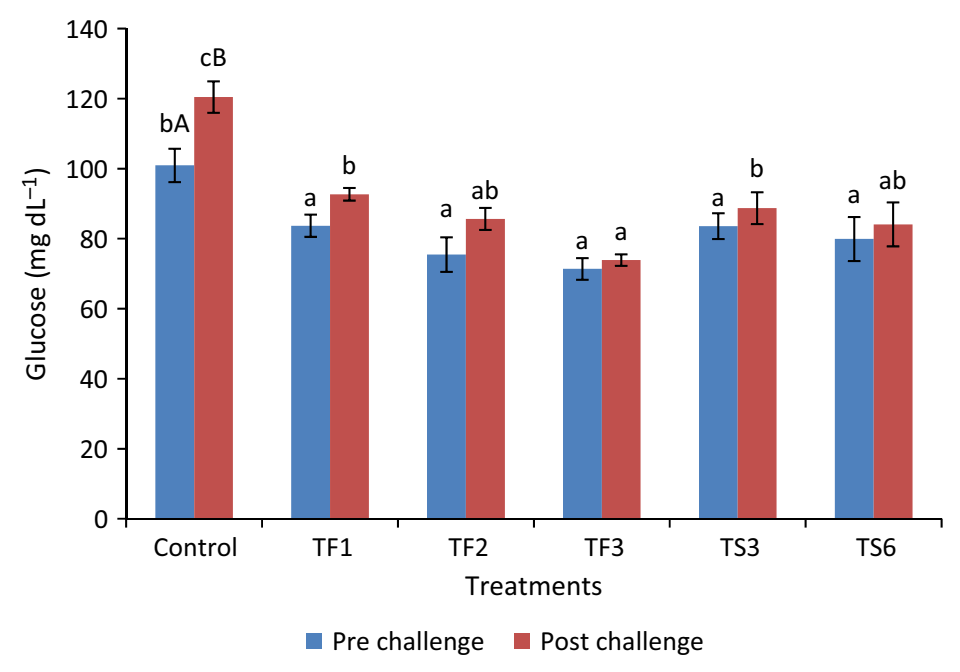

Figure 1 Pre- and post-challenge blood glucose $\left(\mathrm{mg} \mathrm{dL}^{-1}\right)$ of different experimental groups. Mean values in the experimental group with different superscript $(a, b, c)$ differ significantly $(P<0.05)$. Mean values in the experimental groups with different superscript $(\mathrm{A}, \mathrm{B})$ between pre and post challenge group under each treatment vary significantly $(P<0.05)$. Data expressed as Mean $\pm \mathrm{SE} n=3$. Control $-0 \%$ FRSE, $\mathrm{TF}_{1}-1 \%$ FRSE, $\mathrm{TF}_{2}-2 \%$ FRSE, $\mathrm{TF}_{3}-3 \%$ FRSE, $\mathrm{TS}_{3}-3 \%$ seaweed powder, $\mathrm{TS}_{6}-6 \%$ seaweed powder. found among the various treatment groups (Table 4). Feeding of FRSE diet significantly $(P<0.001)$ affected the haemoglobin, TEC and TLC with the highest value in 3\% FRSE diet fed group and the lowest in the control group. Same trend was also noticed in the post-challenged groups. But in case of post challenge condition, TEC values of all the treatments groups were less than their pre-challenged counterpart. The highest haematocrit values in both pre and post challenge conditions were found in $\mathrm{TF}_{3}$ groups which was significantly different from all the other treatment 
groups $(P<0.001)$. There was significant difference in pre and post challenge HCT value in $\mathrm{TF}_{1}$. $\mathrm{TF}_{3}$ and $\mathrm{TS}_{6}$. The lowest HCT value was found in the control groups both in pre and post challenge condition and no significant $(P>0.05)$ difference between pre and post challenge condition.

\section{Respiratory burst activity}

There was significant difference $(P<0.001)$ in the respiratory burst activity among the various treatment groups separately in both pre- and postchallenge conditions (Fig 2). In both, pre and postchallenged groups highest NBT activity was observed in 3\% FRSE diet fed group and least activity was recorded in the control group. There was no significant difference between the pre-challenge group of $\mathrm{TF}_{1}, \mathrm{TS}_{3}$ and $\mathrm{TS}_{6}$ treatments. As well as no significant difference was found among the post challenge group of $\mathrm{TF}_{1}, \mathrm{TF}_{2}, \mathrm{TS}_{3}$ and $\mathrm{TS}_{6}$ groups However, there were no significant $(P>0.05)$ changes in NBT values between pre and post challenge condition of the respective treatment groups i.e. between pre challenge TF1 and post challenge TF1.

\section{Serum protein, albumin, globulin and albumin to globulin ratio}

There was significant difference $(P<0.001)$ in serum protein, albumin, globulin and A/G ratio level among the various treatment groups in both pre and post challenge conditions, separately (Table 5). In both pre and post-challenge condition the serum protein level increased with the increasing FRSE content in the diets. But during the post challenge condition serum protein level was lower than the serum protein content of pre challenge condition. And the values for $\mathrm{TF}_{2}$ and $\mathrm{TF}_{3}$ were similar $(P>0.05)$ in pre and post challenge condition. There was significant difference $(P<0.05)$ between pre and post challenge serum protein in control, $\mathrm{TF}_{2}$ and $\mathrm{TF}_{3}$ experimental groups. Serum globulin content also exhibited the same trend during pre and post challenge condition as like serum protein. Highest serum globulin content was found in $\mathrm{TF}_{3}$ group. The significant difference $(P<0.05)$ between pre and post challenge globulin content was found in control, $\mathrm{TF}_{2}, \mathrm{TF}_{3}$ and $\mathrm{TS}_{6}$ groups.

The pre and post challenge serum albumin content of different experimental groups significantly differs among the different treatments $(P<0.05)$.

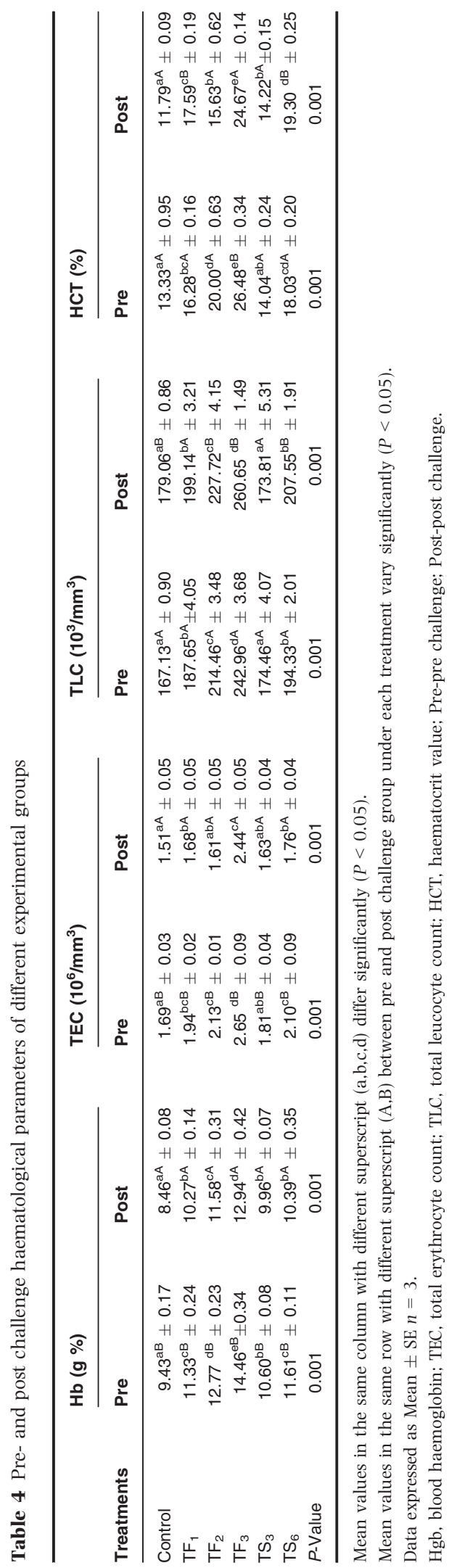




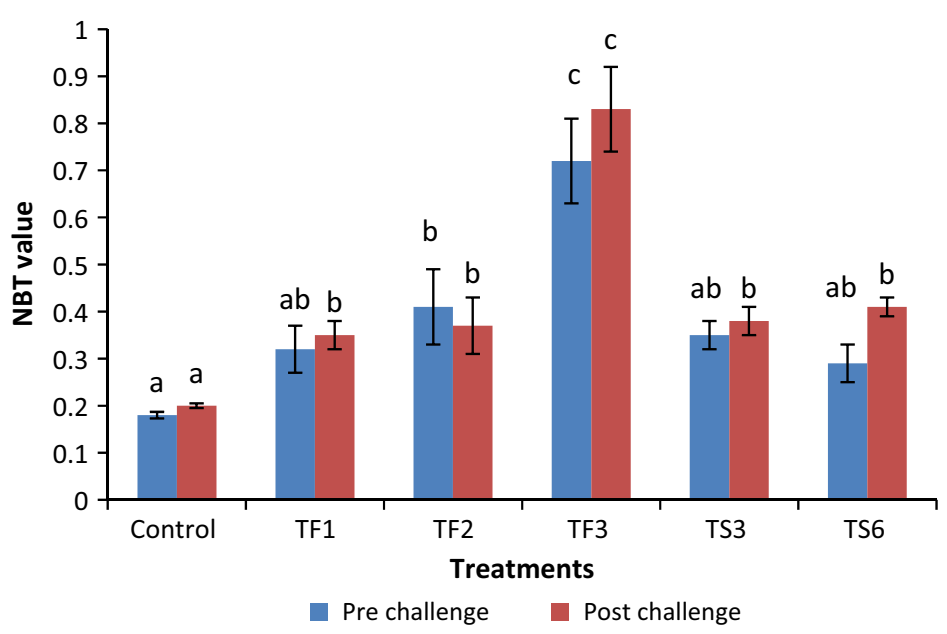

Figure 2 Pre- and post-challenge NBT value of different experimental groups. Mean values in the experimental group with different superscript $(a, b, c)$ differ significantly $(P<0.05)$. Data were expressed as Mean \pm SE $n=3$. Control $-0 \%$ FRSE, $\mathrm{TF}_{1}-1 \%$ FRSE, $\mathrm{TF}_{2}-2 \% \mathrm{FRSE}_{2} \mathrm{TF}_{3}-3 \%$ FRSE, $\mathrm{TS}_{3}-3 \%$ seaweed powder, $\mathrm{TS}_{6}-6 \%$ seaweed powder.

There was significant difference exists between pre and post challenge serum albumin level only in $\mathrm{TF}_{2}$ and $\mathrm{TF}_{3}(P<0.05)$. Highest $\mathrm{A} / \mathrm{G}$ ratio was found in the control groups of both pre and post challenge conditions, whereas least values were recorded in the FRSE fed groups. There was no significant $(P>0.05)$ changes exists between pre and post challenge $A / G$ ratio of different experimental groups except the control group $(P<0.05)$.

\section{Serum lysozyme and phagocytic activity}

In pre-challenge condition, the highest serum lysozyme activity was found in $\mathrm{TF}_{2}$ group $(P<0.001)$, whereas in post-challenge condition the maximum activity recorded in $\mathrm{TF}_{3}$ group $(P<0.001)$. The lowest activity was found in control group in both cases $(P<0.001)$. The post challenged group exhibited significantly higher value than their pre-challenged counterpart. There was clear significant difference $(P<0.05)$ observed between pre and post challenge serum lysozyme activity of all the experimental groups. The serum phagocytic activity and phagocytic index exhibited increasing trend as the increase in FRSE and seaweed powder incorporated diet both in pre and post challenge experimental groups. The higher value of phagocytic activity and phagocytic index was observed in the TF3 experimental treatment in both pre and post challenge condition. There was significant difference $(P<0.001)$ in serum phagocytic activity and phagocytic index among, both the pre and post challenge experimental groups. A clear significant difference $(P<0.05)$ between the pre- and post- challenge serum phagocytic activity, and phagocytic index was noticed due to feeding of fucoidan rich seaweed extract incorporated diet (Table 6).

\section{Cumulative mortality percentage and relative percentage of survival}

There was no mortality recorded in both in $\mathrm{TF}_{2}$ and $\mathrm{TF}_{3}$ group and highest mortality was recorded in the control group when challenged with A. hydrophila (Fig. 3). The survival trend in $\mathrm{TF}_{1}, \mathrm{TS}_{3}$ and $\mathrm{TS}_{6}$ were almost similar. There was no much significant difference in the survival rate of different experimental groups except the control group $(P<0.05)$.

\section{Sequencing and identification of IFN- $\gamma 2$ gene}

Fortunately, we got two different sequences and which were analysed and confirmed as pIFN- $\gamma 2 \mathrm{a}$ and pIFN- $\gamma 2$ b. Sutchi catfish interferon gamma $2 \mathrm{a}$ and $2 \mathrm{~b}$ gene sequences were submitted to the NCBI GenBank and possessing the accession numbers JN 185453 and JN 185454 respectively. pIFN- $\gamma 2$ a and pIFN- $\gamma 2 \mathrm{~b}$ genes showed maximum homology of (89\%) and $88 \%$ with Ictalurus punctatus interferon 
gamma 2a (DQ124250) and 2b (DQ124251) gene sequences respectively. The longer transcript designated IFN- $\gamma 2 \mathrm{a}$ is contains nine additional nucleotides (GTAAGAAAA), which encode the tripeptide val-arg-lys (VRK) found. The shorter transcript, IFN- $\gamma 2 \mathrm{~b}$ is identical to IFN- $\gamma 2 \mathrm{a}$ except for the absence of the nine aforementioned nucleotides.

\section{Semi-quantitative RT PCR analysis and expression level of IFN- $\gamma 2 \mathbf{a}$}

The cDNA samples derived from head kidney collected from differential experiment groups before and $24 \mathrm{~h}$ after infection with $A$. hydrophila were used to examine the expression levels of interferon gamma $2 \mathrm{a}, \beta$-actin was used as reference control to normalize the errors in initial RNA concentration. In pre-challenge condition the expression level of IFN- $\gamma 2$ a level was increased with increasing level of FRSE and seaweed powder incorporated diet fed groups. The expression level was less in control group than all the other experimental groups. In post-challenge condition, though $\mathrm{TF}_{3}$ group show maximum expression there was no marked difference in the expression level of IFN$\gamma 2$ a gene in different experimental groups (Fig. 4) as revealed from Gel-Pro analysis (Fig. 5).

\section{Discussion}

There are plenty of herbal extracts used as immunostimulants in aquaculture to enhance the nonspecific immune system of cultured fish species (Sakai 1999; Rao, Das, Jyotyrmayee \& Chakrabarti 2006; Sahu, Das, Pradhan, Mohapatra, Mishra \& Sarangi 2007; Ardo, Yin, Xu, Varadi, Szigeti, Jeney \& Jeney 2008). The main components of the non-specific immune system are monocytes, granulocytes, neutrophils, macrophages and humoral elements, like lysozyme, agglutinin and metal-ion binding proteins (Secombes \& Fletcher 1992; Sakai 1999; Rao et al. 2006; Sahu, Das, Pradhan et al. 2007; Ardo et al. 2008). Hence, evaluating fish blood parameters might be a useful tool to understand the impact of immunostimulants on fish health. In the present study, fucoidan rich seaweed extract from $S$. wightii was found to have significant stimulatory effect on non-specific immune parameters in $P$. hypophthalmus, following a challenge with $A$. hydrophila.

Several methods were used to extract fucoidan from different species, such as Dictyota mertensis, 
Table 6 Pre- and post-challenge phagocytic activity, phagocytic index and serum lysozyme activity (U mg protein ${ }^{-1}$ ) of different experimental groups

\begin{tabular}{|c|c|c|c|c|c|c|}
\hline \multirow[b]{2}{*}{ Treatments } & \multicolumn{2}{|c|}{ Phagocytic activity (\%) } & \multicolumn{2}{|c|}{ Phagocytic index } & \multicolumn{2}{|c|}{ Serum lysozyme activity } \\
\hline & Pre & Post & Pre & Post & Pre & Post \\
\hline Control & $10.14^{\mathrm{aB}} \pm 0.14$ & $8.58^{\mathrm{aA}} \pm 0.27$ & $1.36^{\mathrm{aB}} \pm 0.02$ & $1.22^{\mathrm{aA}} \pm 0.04$ & $31.48^{\mathrm{aA}} \pm 0.45$ & $42.67^{\mathrm{aB}} \pm 0.91$ \\
\hline $\mathrm{TF}_{1}$ & $10.58^{\mathrm{aA}} \pm 0.39$ & $12.15^{\mathrm{bB}} \pm 0.24$ & $1.44 a^{\mathrm{bA}} \pm 0.01$ & $1.56^{\mathrm{cB}} \pm 0.01$ & $54.44^{\mathrm{cA}} \pm 1.16$ & $66.14^{\mathrm{dB}} \pm 1.10$ \\
\hline $\mathrm{TF}_{2}$ & $14.48^{\mathrm{bA}} \pm 0.57$ & $16.21^{\mathrm{cA}} \pm 0.30$ & $1.62^{\mathrm{cA}} \pm 0.02$ & $1.74^{\mathrm{dB}} \pm 0.03$ & $67.27^{\mathrm{eA}} \pm 0.51$ & $82.30^{\mathrm{eB}} \pm 1.40$ \\
\hline $\mathrm{TF}_{3}$ & $20.70^{\mathrm{CA}} \pm 0.36$ & $23.96^{\mathrm{dB}} \pm 0.85$ & $1.84^{\mathrm{dA}} \pm 0.03$ & $1.97^{\mathrm{eB}} \pm 0.03$ & $60.08^{\mathrm{dA}} \pm 1.93$ & $87.53^{\mathrm{fB}} \pm 1.58$ \\
\hline $\mathrm{TS}_{3}$ & $10.30^{\mathrm{aA}} \pm 0.09$ & $10.80^{\mathrm{abB}} \pm 0.11$ & $1.41^{\mathrm{bA}} \pm 0.02$ & $1.45^{\mathrm{bA}} \pm 0.02$ & $48.65^{\mathrm{bA}} \pm 0.36$ & $52.58^{\mathrm{bB}} \pm 0.62$ \\
\hline $\mathrm{TS}_{6}$ & $12.40^{\mathrm{abA}} \pm 0.74$ & $13.76^{\mathrm{bcA}} \pm 0.78$ & $1.51^{\mathrm{bA}} \pm 0.03$ & $1.55^{\mathrm{cA}} \pm 0.01$ & $54.79^{\mathrm{cA}} \pm 0.93$ & $60.23^{\mathrm{CB}} \pm 1.01$ \\
\hline$P$-value & 0.001 & 0.001 & 0.001 & 0.001 & 0.001 & 0.001 \\
\hline
\end{tabular}

Mean values in the same column with different superscript (a,b,c,d) differ significantly $(P<0.05)$.

Mean values in the same row with different superscript $(A, B)$ between pre and post challenge group under each treatment vary significantly $(P<0.05)$.

Data were expressed as Mean \pm SE $n=3$.

Pre-pre challenge; Post-post challenge.

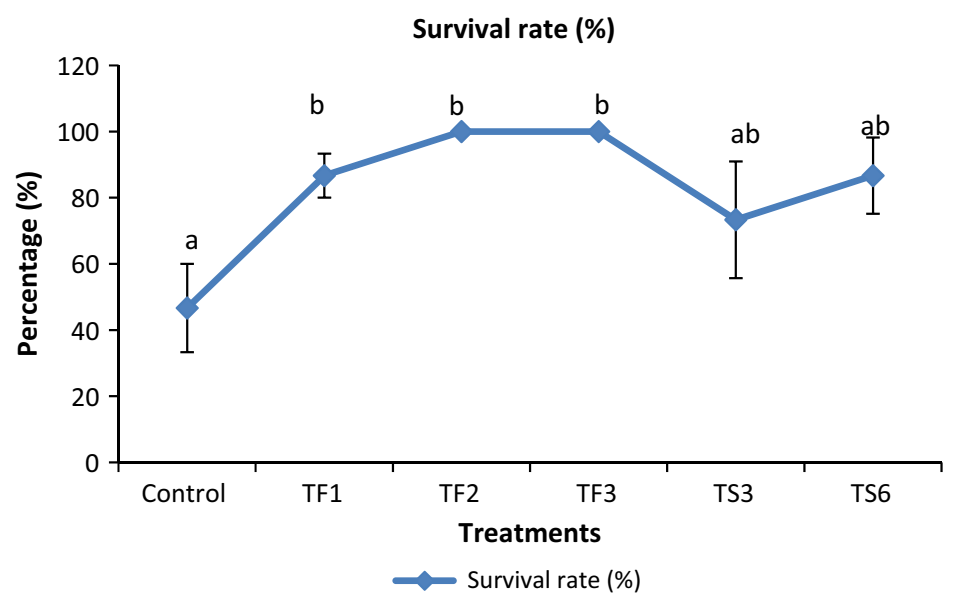

Figure 3 Cumulative relative percentage of survival of $P$. hypophthalmus fingerlings of different experimental group challenged with $A$. hydrophila. Mean values in the experimental group with different superscript $(a, b)$ differ significantly $(P<0.05)$. Data were expressed as Mean \pm SE $n=15$. Control $-0 \%$ FRSE, $\mathrm{TF}_{1}-1 \%$ FRSE, $\mathrm{TF}_{2}-2 \%$ FRSE, $\mathrm{TF}_{3}-3 \%$ FRSE, $\mathrm{TS}_{3}-3 \%$ seaweed powder, $\mathrm{TS}_{6}-6 \%$ seaweed powder.
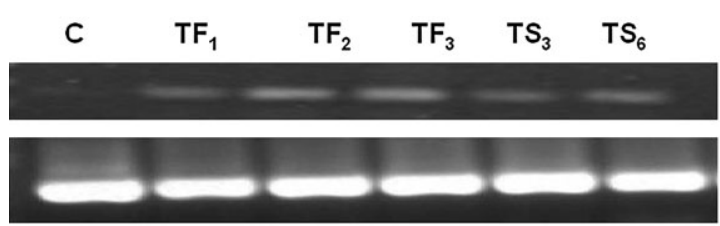

Pre-challenge

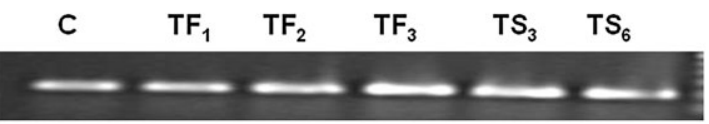

IFN- $\mathrm{Y} 2 \mathrm{a}$

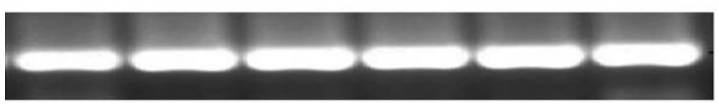

\section{Post-challenge}

Padina gymnospora and Sargassum vulgare by Maxatase (Dietrich, Farias, De Abreu, Leite, De Silva \& Nader 1995), Facus vesiculosus, Laminaria
IFN-Y2a

$\beta$-actin $\beta$-actin

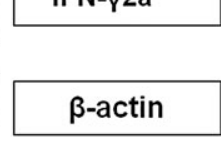

brasiliensis and Ascophyllum nodusum by papain (Pereira, Mulloy \& Mourao 1999), Sargassum horneri by $10 \%$ TCA (Hoshino, Hayashi, Hayashi, 


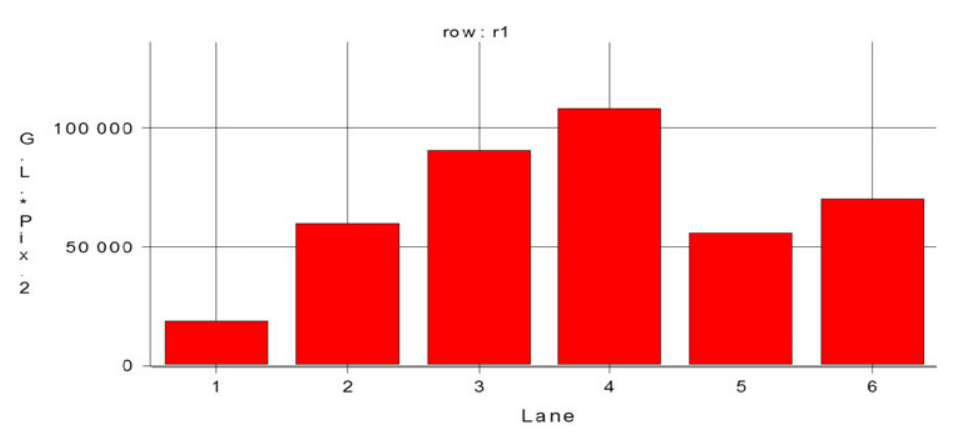

Figure 5 IFN- $\gamma 2$ a expression levels in head kidney tissue before (pre-challenge) and after (post challenge) infection with A. hydrophila sequentially (Gel-Pro analysis). In both the graph the numbers $1,2,3,4,5$ \& 6 represents. $\mathrm{C}-0 \%$ FRSE, $\mathrm{TF}_{1}-1 \%$ FRSE, $\mathrm{TF}_{2}-2 \%$ FRSE, $\mathrm{TF}_{3}-3 \%$ FRSE, $\mathrm{TS}_{3}-3 \%$ seaweed powder and $\mathrm{TS}_{6}-6 \%$ seaweed powder respectively.

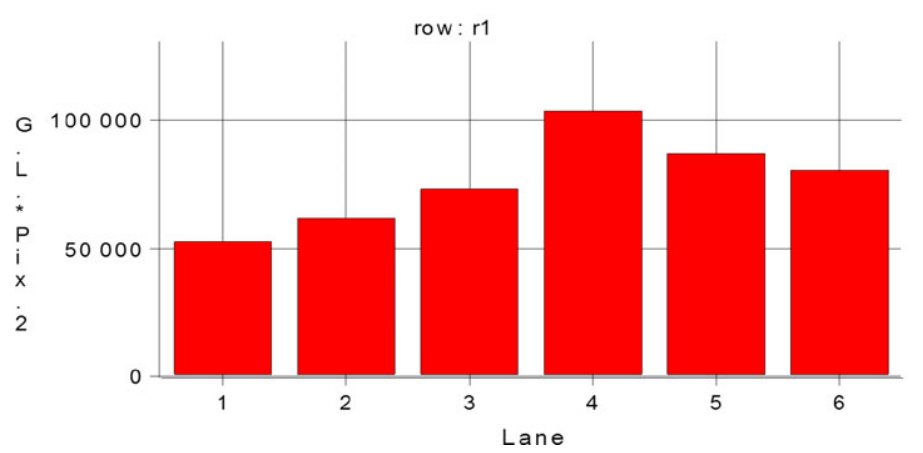

Hamada, Lee \& Sankawa 1998) and Sargassum horneri, Sargassum ilicifolium, Padina canaliculata and Sargassum polycystum by $\mathrm{HCl}$ (Wang \& Zhae 1985; Velayutham \& Jayachandran 1991; Colliec, Vidal \& Jozefonviez 1994; Chotigeat et al. 2004). The yield varied widely, depending on the method used and the seaweed species. In the present study, fucoidan content of Sargassum wightii was $5.5 \%$. This is in agreement with (Wang \& Zhae 1985; Velayutham \& Jayachandran 1991; Eluvakkal, Sivakumar \& Arunkumar 2010), who reported that the fucoidan content from Sargassum wightii, Sargassum ilicifolium and Sargassum horneri was $7.15 \%, 4.2 \%$ and $3.9 \%$ respectively.

In the present study, inclusion level of FRSE and seaweed powder showed significant effect on the weight gain percentage and specific growth rate of the fingerlings of $P$. hypophthalmus than the control group. The current result agrees with the previous findings, indicating the growth-promoting effects of fucoidan in shrimps (Immanuel et al. 2010; Traifalgar et al. 2010). In the present study, FCR was significantly different in FRSE diet fed groups and seaweed power fed groups than the control group. This is expected as there was increase in weight gain due to feeding of different concentration of FRSE. This is in agreement with the results of (Immanuel et al. 2010; Traifalgar et al. 2010) in shrimps. The PER was also signifi- cantly affected $(P<0.005)$ by graded level feeding of FRSE blended diets. Growth rate of P. hypophthalmus fingerling were influenced by the addition of FRSE and seaweed powder in the diet which exhibited better PER achieved by FRSE diet fed groups than the control group. Though the growth promoting effect of fucoidan has not been reported, but indirect role in mitigating stress to growth rate may not be ruled out. Similar result was supported by (Traifalgar et al. 2010) in Marsupenaeus japonicus fed diets supplemented with graded levels of Undaria pinnatifida fucoidan.

A variety of immunostimulants including fucoidan (Chotigeat et al. 2004) stimulate the fish phagocytes such as macrophages and neutrophils. The superoxide anions $\left(\mathrm{O}_{2}{ }^{-}\right)$and its reactive derivatives hydrogen peroxide and free radicals like hydroxyl radicals are produced by fish phagocytes at times of intense oxygen consumption that is known as the respiratory burst activity (Secombes \& Fletcher 1992; Secombes 1996). These generated reactive oxygen species (ROS) are considered to be harmful for fish pathogenic bacteria (Hardie, Ellis \& Secombes 1996; Itou, Lida \& Kawatsu 1996). Thus, phagocytes play a vital role in limiting the dispersion of infectious agents and are responsible for the eventual destruction of phagocytosed pathogens by evolving elaborate killing mechanisms such as degranulation and 
production of reactive oxygen and nitrogen intermediates (Neumann, Stafford, Barreda, Ainsworth \& Belosevic 2001). The degranulation is necessary for the release of Myeloperoxidase (MPO) and diverse antimicrobial enzymes (Quade \& Roth 1997). Hence, increased respiratory burst activity can be positively correlated with the increased bacterial pathogen killing activity of fish phagocytes (Sharp \& Secombes 1993). The respiratory burst activity of phagocytes was measured by reduction in nitroblue tetrezolium (NBT) by intracellular superoxide radicals produced by the fish leucocytes (Siwicki \& Studnica 1987; Sahu, Das, Pradhan et al. 2007; Ardo et al. 2008). In the present study, an increasing trend of NBT was observed before and after challenge study with increasing level of FRSE fed groups. Higher NBT value was registered in $\mathrm{TF}_{3}$ group supplemented with 3\% of FRSE suggesting the immuno-protecting role of fucoidan. This is in agreement with the enhanced NBT activity in Labeo rohita fed with varying levels of garlic incorporated feed (Sahu, Das, Misra, Pradhan \& Sarangi 2007).

Resistance of fish to infection by microorganisms relies mostly on an immediate response carried out by cells and serum soluble molecules. Phagocytic activity is strongly influenced by immunostimulants, possibly due to their high demand for antioxidative substances necessary for preventing oxidative damage induced by free radicals produced to counteract pathogen aggression (Wahli, Verlhac, Gabaudan, Schuep \& Meier 1998). Phagocytosis and other killing mechanism of phagocytic cells are an important defence mechanism against pathogenic bacteria in fish (Rao et al. 2006). In the present study, phagocytic activity increased with the increasing level of dietary FRSE. The highest phagocytic activity was found in the groups fed with 3\% FRSE and the lowest was noticed in the control group. After infection with A. hydrophila, the phagocytic activity was again increased in all the treatments with maximum hike in the $\mathrm{TF}_{3}$ groups as like the pre-challenge condition. Phagocytic index also followed the same trend as like the phagocytic activity. The increased phagocytic activity also proved by increase in the NBT activity. This result is similar to the phagocytic activity of vitamin C (Tewary \& Patra 2008) and mango kernel (Sahu, Das, Pradhan et al. 2007) on Labeo rohita and diet containing active component of Ocimum sanctum, Withania somnifera and Myristica fragrans on Epinephelus tauvina juveniles (Sivaram, Babu, Immanul, Murugadass, Citarasu \& Petermarian 2004).

Head kidney is essential for erythropoietin production (Gordon, Goper \& Zaryani 1967) and any damage in it cause decrease in erythropoietin level, which in turn decreases RBC production and Hb synthesis even under hypoxic conditions (Reddy, Vijayakumari, Kalarani \& Davies 1992). Immunostimulants have the potential to improve the function of head kidney meanwhile augmenting the erythropoiesis and haematosynthesis. In the present study, increased FRSE fed groups exhibited higher $(P<0.05)$ erythrocyte count than the control group. Erythrocyte number was significantly higher in fish fed with 3.0\% FRSE incorporated diet. Since, the TEC value increased, haematocrit value was also increased gradually with the increasing concentration of FRSE in the diet. This is agreement with the previous findings (Sahu, Das, Pradhan et al. 2007; Mohamad \& Abasali 2010). Erythrocyte count and haemoglobin level significantly decreased $(P<0.05)$ in the post-challenge period which is observed in the previous studies in Nile Tilapia (Ranzani-Paiva, Ishikawa, Eiras \& Silveira 2004) and Rohu (Misra et al. 2006). During post-challenge, the decrease in the haemoglobin content in present study is correlates with the study in which furunculosis caused by $A$. salmonicida in Atlantic salmon (Foda 1973). The same kinds of results were also reported in Etroplus suratensis (Pathiratne \& Rajapakshe 1998) and Cyprinus carpio (Harikrishnan, Nisha \& Balasundaram 2003). The decrease in Hct and haemoglobin concentration of fish exposed to A. hydrophila indicates that the RBCs are being destroyed by the leucocytosis activity in an erythrocytic anaemia with subsequent erythroblastosis on erythropoietic organs (Haney, Hursh, Mix \& Winton 1992).

The leucocytes play an essential role in non-specific immunity of fish and that can be evident from their count which can be considered as a good indicator of the health status of any fish along with other immunological parameters (Roberts 1978). During inflammation leucocytes possess a significant role. At times of infection, the increase in leucocytes probably represents the inflammatory response against the bacteria (Roberts 1978). In the present study, the leucocytes count was higher in $\mathrm{TF}_{3}$ group which was significantly higher than the control group, which may be due to immune-modulatory response of dietary FRSE. Similar observation was made in rohu fingerlings 
when fed with yeast RNA incorporated diet (Choudhury, Pal, Sahu, Kumar, Das \& Mukherjee 2005) and dietary carbohydrate as well as n-3 PUFA (Misra et al. 2006) and catla fingerlings fed dietary yeast RNA, $\omega$-3 fatty acid and $\beta$-carotene as immunostimulants (Jha, Pal, Sahu, Kumar \& Mukherjee 2007).

Fish serum lysozyme is produced by leukocytes including neutrophils and macrophages. A total lysozyme level is a measurable humoral component of the non-specific defence mechanism which has the potential to prevent the growth of pathogenic bacteria by splitting beta-1, 4 glycosidic bonds between $\mathrm{N}$-acetylmuramic acid and $\mathrm{N}$-acetylglucosamine in the peptidoglycan of bacterial cell walls and hence stimulating the phagocytosis of pathogenic bacteria (Ellis 1990; Alexander \& Ingram 1992; Gopalakannan \& Arul 2006; Choi, Park, Yoon, Kim, Jang \& Choe 2008). Increased levels of lysozyme activity are known to possess natural protective mechanism in fish (Ingram 1980). Umpteen numbers of reports are available in which immunostimulants can enhance the lysozyme activity (Chen, Wu, Yin \& Li 2003; Puangkaew, Kiran, Somsmoto, Okamoto, Satoh \& Takeuchi 2004; Hanif, Bakopoulos, Leonardos \& Dimitriadis 2005). In the present study, serum lysozyme activity was also found an increasing trend as that of NBT which is in agreement with Fenneropenaeus chinensis fed with Sargassum fusiforme polysaccharide extracts (Huang et al. 2006) and Labeo rohita fed with levamisole (Wijendra \& Pathiratne 2007).

After challenged with $A$. hydrophila the serum lysozyme activity was increased in the experimental groups as the concentration of FRSE level increased in the diet. The present result is correlated with the observations made in common carp, C. carpio that exhibited an increased serum lysozyme activity after challenge with A. punctata (Vladimirov 1968; Siwicki \& Studnica 1987) and in Atlantic salmon which had challenged with A. salmonicida (Møyner, Røed, Sevtdal \& Heum 1993). The level of serum lysozyme was enhanced in Labeo rohita and Anguilla japonica after feeding with Achyranthes aspera seed (Rao et al. 2006) and extract of Viscum album (Choi et al. 2008) respectively. The Paralichthys olivaceous challenged with Edwardsiella tarda, exhibits increased synthesis of serum lysozyme (Hilima, Hirono \& Aoki 1997). The production of serum lysozyme by Atlantic salmon macrophages in vitro is enhanced in the presence of yeast glucan or bacterial lipopolysaccharide as an immunostimulant (Lamas \& Ellis 1994). After pathogenic bacterial challenge, in most of the fish a significant increase in the numbers of leukocytes could supports the results of present study and that is the indication of activation of the non-specific immune system in the infected fish.

The serum proteins includes various humoral elements of the non-specific immune system, measurable total protein, albumin and globulin levels suggests that high concentrations are likely to be a result of the enhancement of the non-specific immune response of fish. In the present study, highest plasma protein, albumin and globulin content were found in 3\% FRSE fed groups during pre-challenge. It was observed that serum protein, albumin and globulin level was increased steadily with the increasing FRSE level in the diet than the control group fish. The higher serum globulin level during the pre-challenge period was reported in $L$. rohita (Kumar, Sahu, Pal, Choudhury, Yengkokpam \& Mukherjee 2005; Misra et al. 2006) since, globulins are vital for maintaining a healthy immune system because of the presence of immune-globulin in the blood. Lower albumin/ globulin ratio indicates the presence of more amounts of globulin which was found in $\mathrm{TF}_{3}$ group, indicating more globulin fraction may be induced by FRSE, which can be correlated with other immunological indices like increased phagocytic activity and leucocytes count in this experiment. After challenge with $A$. hydrophila the serum protein and globulin level was decreased than their pre-challenged counterpart but the albumin fraction was comparatively higher than the pre-challenged condition. After challenge with pathogenic bacteria, reduction in serum protein level might be due to leakage of serum protein through the walls of vascular tissues because of its highly enhanced permeability (Green 1978; Ellis, Hastings \& Munro 1981) even though the destruction of RBCs and the resultant release of cell contents into the blood stream (Haney et al. 1992) and also together with improper synthesis of serum protein and its non-specific proteolysis. (Ellis et al. 1981).

The determination of blood glucose level is considered as an efficient method to evaluate the stress caused by variety of stressors including physical factors (Manush, Pal, Das \& Mukherjee 2005) and pollutants (Svobodova 1971). Umpteen 
numbers of literatures are available on the level of glucose associated with different stressors including ablation of claws in prawns (Manush et al. 2005), harsh handling (Wedemeyer 1972; Carey \& McCormick 1998) adverse effect of transportation (Barton \& Schreck 1987) and increased packing density (Chatterjee, Pal, Das, Manush, Sarma, Venkateshwarlu \& Mukherjee 2006). All types of stress elevated the secretion of catecholamines which in turn increases the breakdown of glycogen and enhanced the level of blood glucose (Nakano \& Tomlinson 1967). The elevated glucose level in the infected or stressed animals is known to ward off the infection or stress (Citarasu, Sivaram, Immanuel, Rout \& Murugan 2006). In the present study, an inverse relationship between glucose level and increasing level of FRSE in the diet was observed. As the level of FRSE increased in the diet, the level of glucose decreased. This might be due to the capability of FRSE to reduce the effects of stressors. The highest blood glucose level was found in the control group than the FRSE diet fed groups. Though blood glucose content increased in all the treatments during post challenge period but FRSE diet fed groups exhibited the less glucose level than the control group. Lower blood glucose content in the treatment groups compare with the control after challenged with $A$. hydrophila, appears to be FRSE effects in reducing the stress of $P$. hypophthalmus fingerlings.

The ability of different substances to increase macrophage activity is known in fish but far less is known about the potential interaction of such signals. These interactions can be possible in fish as seen in mammals, in the case of interferon- $\gamma$ (IFN- $\gamma$ ) and LPS which are required to induce macrophage activation. In the present study, the expression level of IFN- $\gamma 2$ a gene before the challenge with bacteria was increased with increasing level of FRSE in the diet. A notable increase was observed in the expression level of IFN- $\gamma 2$ a gene after $A$. hydrophila infection than the pre-challenged condition but there were not much difference among the different experimental groups. This is in agreement with, the head kidney tissue exhibited better expression profiles of the IFN- $\gamma$ gene in healthy and viral haemorrhagic septicaemia virus (VHSV) challenged Japanese flounder fish which result in $24 \mathrm{~h}$ duration shows maximum expression in VHSV challenged kidney tissue (Matsuyama, Fujiwara, Sakai \& Nakayasu 2008). But there is no work with reference to bacterial infection. Further study is necessary for better understanding of expression of IFN- $\gamma 2$ a gene with relates to bacterial infection.

In this study, the highest relative percentage of survival was recorded in $\mathrm{TF}_{3}$ and $\mathrm{TF}_{2}$ group followed by $\mathrm{TF}_{1}$ and $\mathrm{TS}_{6}$ group which indicates that supplementation of FRSE had a positive influence on the survival of $P$. hypophthalmus fingerlings by resisting the $A$. hydrophila infection. It has been previously reported by many authors that fucoidan benefit many elements in the immune system. In the present study, it has been found that after challenge with $A$. hydrophila, serum lysozyme activity, phagocytic activity and expression of interferon- $\gamma$ gene of different treatment groups were higher than the pre-challenge treatment groups (Chotigeat et al. 2004; Huang et al. 2006; Matsuyama et al. 2008).

\section{Conclusion}

The present study reveals that the administration of fucoidan rich seaweed extract enhanced the non-specific immune parameters and disease resistance against $A$. hydrophila in P. hypophthalmus. Hence, it can be concluded that, the sulphur esters exists in the FRSE may enhance the production of macrophages and cytokines through non-specific defence mechanism along with the interlinked antibodies production through the specific defence mechanism for the response of $A$. hydrophila infection to protect the host against red disease. Although the inclusion of seaweed powder exhibit moderately good immunostimulatory activity due to the presence of considerable amount of alginic acid (a potential immunostimulant) along with the fucoidan content but the inclusion of high quantity of seaweed powder affects the colour and texture of the commercial feed due to the pigments and colloidal property of seaweed respectively. Hence, FRSE can be effectively and extensively used as an immunostimulants in fish feed.

\section{Acknowledgments}

The authors are grateful to Director, Central Institute of Fisheries Education, Mumbai, for providing the necessary facilities to carry out this research work. 


\section{References}

Alexander J.B. \& Ingram G.A. (1992) Noncellular nonspecific defense mechanisms of fish. Annual Review of Fish Diseases 2, 249-279.

Anderson D.P. \& Siwicki A.K. (1995) Basic haematology and serology for fish health programs. In: Diseases in Asian Aquaculture II (ed. by M. Shariff, J.R. Arthur \& R.P. Subasinghe), pp. 185-202. Fish Health Section, Asian Fisheries Society, Philippines.

Aoki T. (1992) Chemotherapy and drug resistance in fish farms in Japan. In: Diseases in Asian Aquaculture (ed. by M. Shariff, R.P. Subasighe \& J.R. Arthur) Vol. 1, pp. 519-529. Fish Health Section, Asian Fisheries Society, Philippines.

Ardo L., Yin G., Xu P., Varadi L., Szigeti G., Jeney Z. \& Jeney G. (2008) Chinese herbs (Astragalus membranaceus and Lonicera japonica) and boron enhance the non specific immune response of Nile tilapia (Oreochromis niloticus) and resistance against Aeromonas hydrophila. Aquaculture 275, 26-33.

Barton B.A. \& Schreck C.B. (1987) Influnce of acclimation temperature on interrenal and carbohydrate stress responses in juvenile Chinook salmon (Oncorhynchus tshawytscha). Aquaculture 62, 299-310.

Carey J.B. \& McCormick S.D. (1998) Atlantic salmon smolts are more responsive to an acute handling and confinement stress than parr. Aquaculture 168, 237253.

Castro R., Zarra I. \& Lamas J. (2004) Water-soluble seaweed extracts modulate the respiratory burst activity of turbot phagocytes. Aquaculture 229, 67-78.

Chatterjee N., Pal A.K., Das T., Manush S.M., Sarma K., Venkateshwarlu G. \& Mukherjee S.C. (2006) Secondary stress response in Indian major carps Labeo rohita (Ham), Catla catla (Ham) and Cirrhinus mrigala (Ham) fry to increasing packing densities. Aquaculture Research 37, 472-476.

Chen X., Wu Z., Yin J. \& Li L. (2003) Effects of four species of herbs on immune function of Carassius auratus gibelio. Journal of Fishery Sciences of China 10, 36-40.

Choi S.H., Park K.H., Yoon T.J., Kim J.B., Jang Y.S. \& Choe C.S. (2008) Dietary Korean mistletoe enhances cellular non-specific immune responses and survival of Japanese eel (Anguilla japonica). Fish and Shellfish Immunology 24, 67-73.

Choosawad D., Leggat U., Dechsukhum C., Phongdara A. $\&$ Chotigeat W. (2005) Anti-tumour activities of fucoidan from the aquatic plant Utricularia aurea lour. Songklanakarin Journal of Science and Technology 27, 799-807.

Chotigeat W., Tongsupa S., Supamataya K. \& Phongdara A. (2004) Effect of Fucoidan on disease resistance of black tiger shrimp. Aquaculture 233, 23-30.

Choudhury D., Pal A.K., Sahu N.P., Kumar S., Das S.S. \& Mukherjee S.C. (2005) Dietary yeast RNA supplementation reduces mortality by Aeromonas hydrophila in rohu (Labeo rohita) juveniles. Fish Shellfish Immunology 19, 281-291.

Christybapita D., Divyagnaneswari M. \& Michael R.D. (2007) Oral administration of Eclipta alba leaf aqueous extract enhances the non-specific immune responses and disease resistance of Oreochromis mossambicus. Fish and Shellfish Immunology 23, 840-852.

Citarasu T., Sivaram V., Immanuel G., Rout N. \& Murugan V. (2006) Influence of selected Indian immunostimulant herbs against White Spot Syndrome Virus (WSSV) infection in black tiger shrimp, Penaeus monodon with reference to haematological, biochemical and immunological changes. Fish and Shellfish Iттиnology 21, 372-384.

Colliec S., Vidal C.B. \& Jozefonviez J. (1994) A low molecular weight fucoidan fraction from the brown seaweed Pelvetia canaliculata. Journal of Phytochemistry 35, 697700.

Cruz-Suárez L.E., Hernández J., Porchas-Cornejo M., Coronado-Molina D.E., Linné-Unzueta-Bustamante M.L., Nieto-López M., Tapia-Salazar M. \& Ricque-Marie D. (2007) Fucoidan extracted from the brown algae Cladosiphon okamuranus has been shown to be effective against WSSV in the white shrimp Litopenaeus vannamei. Aquaculture Asia Pacific 3, 19.

Dietrich C.P., Farias G.G.M., De Abreu L.R.D., Leite E.L., De Silva L.F. \& Nader H.B. (1995) A new approach for the characterization of polysaccharides from algae: presence of four main acidic polysaccharides in three species of class Phaeophycea. Plant Science 108, 143153.

Doner L.W. \& Whistler R.L. (1973) Fucoidan: Industrial Gums, Polysaccharides and their Derivatives. Academic Press, New York, pp. 115-120.

Doumas B.T. \& Biggs H.G. (1972) Determination of serum albumin. In: Standard Methods of Clinical Chemistry, Vol. 7 (ed. by G.A. Cooper), pp. 175. Academic Press, New York.

Dubois M., Gilles K.A., Hamilton J.K., Rebers D.A. \& Smith F. (1956) Colorimetric methods for the determination of sugars and related substances. Analytical Chemistry 28, 350-352.

Ellis A.E. (1990) Lysozyme assays. In: Techniques in Fish Immunology (ed. by J.S. Stolen, T.C. Fletcher, B.S. Anderson \& W.B. Van Muiswinkel), pp. 101-103. SOS Publications, New Jersey.

Ellis A.E., Hastings T.S. \& Munro A.L.S. (1981) The role of Aeromonas salmonicida extracellular products in the pathology of furunculosis. Journal of Fish Diseases 4 , 41-52.

Eluvakkal T., Sivakumar S.R. \& Arunkumar K. (2010) Fucoidan in some Indian brown seaweeds found along the coast Gulf of Mannar. International Journal of Botany 6, 176-181.

Foda A. (1973) Changes in hematocrit and hemoglobin in Atlantic salmon (Salmo salar) as a result of 
furunculosis disease. Journal of the Fisheries Research Board of Canada 30, 467-468.

Gopalakannan A. \& Arul V. (2006) Immunomodulatory effects of dietary intake of chitin, chitosan and levamisole on the immune system of Cyprinus carpio and control of Aeromonas hydrophila infection in ponds. Aquaculture 255, 179-187.

Gordon A.S., Goper G.N. \& Zaryani E.D. (1967) The kidney and erythropoiesis. Seminars in Haematology $\mathbf{4}$, 337-343.

Green J.H. (1978) Basic Clinical Physiology, (3rd edn). Oxford University Press, USA, 192pp.

Haney D.C., Hursh D.A., Mix M.C. \& Winton J.R. (1992) Physiological and hematological changes in chumsalmon artificially infected with erythrocytic necrosis virus. Journal of Aquatic Animal Health 4, 48-57.

Hanif A., Bakopoulos V., Leonardos I. \& Dimitriadis G.J. (2005) The effect of seabream (Sparus aurata) broodstock and larval vaccination on the susceptibility by Photobacterium damsel subsp. Piscidida and on the humoral immune parameters. Fish and Shellfish Iттиnology 19, 345-361.

Hardie L.J., Ellis A.E. \& Secombes C.J. (1996) In vitro activation of rainbow trout macrophages stimulates inhibition of Renibacterium salmoninarum growth concomitant with augmented generation of respiratory burst productions. Diseases of Aquatic Organisms 25 , $175-183$.

Harikrishnan R., Nisha Rani M. \& Balasundaram C. (2003) Hematological and biochemical parameters in common carp, Cyprinus carpio, following herbal treatment for Aeromonas hydrophila infection. Aquaculture 221, 41-50.

Hilima J.I., Hirono I. \& Aoki T.S. (1997) Characterisation and expression of c-type lysozyme cDNA from Japanese flounder (Paralichthys olivaceous). Molecular Marine Biology and Biotechnology 6, 339-345.

Hoshino T., Hayashi T., Hayashi K., Hamada J., Lee J.B. \& Sankawa U. (1998) An antivirally active sulfated polysaccharide from Sargassum horneri (TURNER) C. AGARDH. Biological Pharmacological Bulletin 21, 730-734.

Huang X., Zhou H. \& Zhang H. (2006) The effect of Sargassum fusiforme polysaccharide extracts on vibriosis resistance and immune activity of the shrimp, Fenneropenaeus chinensis. Fish and Shellfish Immunology $\mathbf{2 0}$, 750-757.

Immanuel G., Sivagnanavelmurugan M., Balasubramanian V. \& Palavesam A. (2010) Effect of hot water extracts of brown seaweeds Sargassum spp. on growth and resistance to white spot syndrome virus in shrimp Penaeus monodon postlarvae. Aquaculture Research 41, 545-553.

Ingram G.A. (1980) Substances involved in the natural resistance of fish to infection- A Review. Journal of Fish Biology. 16, 23-60.

Itou T., Lida T. \& Kawatsu H. (1996) Kinetics of oxygen metabolism during respiratory burst in Japanese eel neutrophils. Developmental and Comparative Immunology 20, 323-330.

Jha A.K., Pal A.K., Sahu N.P., Kumar S. \& Mukherjee S.C. (2007) Haemato-immunological responses to dietary yeast RNA, $\omega-3$ fatty acid and $\beta$-carotene in Catla catla juveniles. Fish Shellfish Immunology 23, 917927.

Kima M.H. \& Joo H.G. (2008) Immunostimulatory effects of fucoidan on bone marrow-derived dendritic cells. Immunology Letters 115, 138-143.

Kumar S., Sahu N.P., Pal A.K., Choudhury D., Yengkokpam S. \& Mukherjee S.C. (2005) Effect of dietary carbohydrate on haematology, respiratory burst activity and histological changes in L. rohita juveniles. Fish and Shellfish Immunology 19, 331-344.

Lamas J. \& Ellis A.E. (1994) Atlantic salmon (Salmo salar) neutrophil responses to Aeromonas salmonicida. Fish and Shellfish Immunology 4, 210-219.

Manush S.M., Pal A.K., Das T. \& Mukherjee S.C. (2005) Dietary high protein \& vitamin $\mathrm{C}$ influences in mitigating stress due to chelate claw ablation in Macrobrachium rosenbergii males. Comparative Biochemistry and Physiology 142, 10-18.

Maruyama H., Tamauchi H., Iizuka M. \& Nakano T. (2006) The role of NK cells in antitumor activity of dietary fucoidan from Undaria pinnatifida sporophylls (Mekabu). Planta Medica 72, 1415-1417.

Matsuyama T., Fujiwara A., Sakai T. \& Nakayasu C. (2008) Molecular cloning and expression analysis of interferon gamma gene in Japanese flounder Paralichthys olivaceus. Fisheries Science, 75, 253-255.

Misra S., Sahu N.P., Pal A.K., Xavier B., Kumar S. \& Mukherjee S.C. (2006) Pre- and post-challenge immuno-haematological changes in Labeo rohita juv eniles fed gelatinised or non-gelatinised carbohydrate with n-3 PUFA. Fish and Shellfish Immunology 21, 346-356.

Mohamad S. \& Abasali H. (2010) Effect of Plant Extracts Supplemented Diets on Immunity and Resistance to Aeromonas hydrophila in Common Carp Cyprinus carpio. Research Journal of Animal Sciences 4, 26-34.

Møyner K., Røed K.H., Sevtdal S. \& Heum M. (1993) Changes in nonspecific immune parameters in Atlantic salmon (Salmo salar L.), induced by Aeromonas salmonicida infection. Fish and Shellfish Immunology 3, 253265.

Nakano T. \& Tomlinson N. (1967) Catecholamine and carbohydrate concentrations in rainbow trout (Salmo gairdneri) in relation to physical disturbance. Journal of Fisheries Research Board of Canada 24, 17011715.

Neumann N.F., Stafford J.L., Barreda D., Ainsworth A.J. \& Belosevic M. (2001) Antimicrobial mechanisms of fish phagocytes and their role in host defence. Developmental and Comparative Immunology 25, 807-825. 
Oser B.L. (1944) Hawk's Physiological Chemistry (14th edn), pp. 1054-1055. McGraw Hill Publication, New York.

Pathiratne A. \& Rajapakshe W. (1998) Hematological changes associated with epizootic ulcerative syndrome in the Asian cichlid fish Etroplus suratensis. Asian Fisheries Science 11, 203-211.

Pereira M.S., Mulloy B. \& Mourao P.A.S. (1999) Structure and anticoagulant activity of sulfated fucans. Journal of Biological Chemistry 274, 7656-7667.

Puangkaew J., Kiran V., Somsmoto T., Okamoto N., Satoh S. \& Takeuchi T. (2004) Non-specific immune response of rainbow trout (Oncorhynchus mykiss) in relation to different status of vitamin-E and highly unsaturated fatty acids. Fish and Shellfish Immunology 16, 25-39.

Quade M.J. \& Roth J.A. (1997) A rapid, direct assay to measure degranulation of bovine neutrophil primary granules. Veterinary Immunology and Immunopathology 58, 239-248.

Ranzani-Paiva M.J.T., Ishikawa C.M., Eiras A.C. \& Silveira V.R. (2004) Effects of an experimental challenge with Mycobacterium marinum on the blood parameters of Nile Tilapia, Oreochromis niloticus (Linnaeus, 1757). Brazilian Archives of Biology and Technology 47, 945953.

Rao Y.V., Das B.K., Jyotyrmayee P. \& Chakrabarti R. (2006) Effect of Achyranthes aspera on the immunity and survival of Labeo rohita infected with Aeromonas hydrophila. Fish and Shellfish Immunology 20, 263-273.

Reddy D.C., Vijayakumari P., Kalarani V. \& Davies R.W. (1992) Changes in erythropoitic activity of Sarotherodon mossambicus exposed to sublethal concentrations of the herbicide diuron. Bulletin of Environmental Contamination and Toxicology 49, 730-737.

Reinhold J.G. (1953) Manual determination of serum total protein, albumin and globulin fractions by Biuret method. In: Standard Method of Clinical Chemistry (ed. by M. Reiner), p. 88. Academic Press, New York.

Ren-na S.A., Jian-ming T., Chun-nian H.E., Wei-wei G.A.O. \& Qi Z. (2008) Effect of fucoidan and fraction isolated from Laminaria japonica on immunity of broiler macrophages under oxidation stress condition. Scientia Agricultura Sinica 41, 1482-1488.

Roberts R.J. (1978) The pathophysiology and systemic pathology of teleosts. In: Fish Pathology (ed. by R.J. Roberts), pp. 55-91. Bailliere Tindal, London.

Sahu S., Das B.K., Pradhan J., Mohapatra B.C., Mishra B.K. \& Sarangi N.N. (2007) Effect of Mangifera indica kernel as a feed additive on immunity and resistance to Aeromonas hydrophila in Labeo rohita fingerlings. Fish and Shellfish Immunology 23, 109-118.

Sahu S., Das B.K., Misra B.K., Pradhan J. \& Sarangi N.N. (2007) Effect of Allium sativum on the immunity and survival of Labeo rohita infected with Aeromonas hydrophila. Journal of Applied Ichthyology 22, 1-6.
Sakai M. (1999) Current research status of fish immunostimulants. Aquaculture 172, 63-92.

Secombes C.J. (1990) Isolation of Salmonid macrophage and analysis of their killing activity. In: Techniques in Fish Immunology (ed. by J.S. Stolen, T.C. Fletcher \& D.P. Anderson), pp. 137-152. SOS Publication, New Jersey.

Secombes C.J. (1996) The nonspecific immune system: cellular defences. In: The Fish Immune System, Organism, Pathogen and Environment (ed. by G. Iwama \& T. Nakanishi), pp. 63-103. Academic Press, Toronto.

Secombes C.J. \& Fletcher T.C. (1992) The role of phagocytes in the protective mechanisms of fish. Annual Review Fish Diseases 2, 53-71.

Sharp G.J.E. \& Secombes C.J. (1993) The role of reactive oxygen species in the killing of the bacterial fish pathogen Aeromonas salmonicida by rainbow trout macrophages. Fish and Shellfish Immunology 3, 119 129.

Sivaram V., Babu M.M., Immanul G., Murugadass S., Citarasu T. \& Petermarian M. (2004) Growth and immunoresponse of juvenile greasy groupers (Epinephelus tauvina) fed with herbal antibacterial active principle supplemented diets against Vibrio harveyi infection. Aquaculture 237, 9-20.

Siwicki A. \& Studnica M. (1987) The phagocytic ability of neutrophils and serum lysozyme activity in experimentally infected carp, Cyprinus carpio. Journal of Fish Biology 31, 57-60.

Stasiack A.S. \& Bauman C.P. (1996) Neutrophil activity as a potent indicator of concomitant analysis. Fish and Shellfish Immunology 37, 539.

Svobodova Z. (1971) Some haematological and metabolic changes in fish occurring after pesticide intoxication. Bulletin Vurh Vodnany 7, 29-36.

Takahashi Y., Uehara K., Watanabe R., Okumura T., Yamashita T., Omura H., Yomo T., Kawano T., Kanemitsu A., Narasaka H., Suzuki N. \& Itami T. (1998) Efficacy of oral administration of fucoidan, a sulfated polysaccharide, in controlling white spot syndrome in Kuruma shrimp in Japan. In: Advances in Shrimp Biotechnology (ed. by T.W. Flegel), pp. 171-173. National Center for Genetic Engineering and Biotechnology, Bangkok.

Tewary A. \& Patra B.C. (2008) Use of vitamin C as an immunostimulant. Effect on growth, nutritional quality, and immune response of Labeo rohita (Ham.). Fish Physiology and Biochemistry 34, 251-259.

Traifalgar R.F., Kira H., Tung H.T., Michael F.R., Laining A., Yokoyama S., Ishikawa M. \& Koshio S. (2010) Influence of dietary fucoidan supplementation on growth and immunological response of juvenile Marsupenaeus japonicas. Journal of World Aquaculture Society 41, 235-244.

Velayutham P. \& Jayachandran P. (1991) Isolation and purification of fucoidan, laminarian and alginate from 
Sargassum ilicifolium. Seaweed Research Utilization 13 , 49-50.

Vladimirov V.L. (1968) Immunity in fish. Bulletin - Office International des Épizooties 69, 1365-1372.

Wahli T., Verlhac V., Gabaudan J., Schuep W. \& Meier W. (1998) Influence of combined vitamins $C$ and $E$ on non-specific immunity and disease resistance of rainbow trout, Oncorhynchus mykiss (Walbaum). Journal of Fish Diseases 21, 127-137.

Wang Z. \& Zhae X. (1985) Extraction and isolation of alginic acid, laminaria and fucoidan from Sargassum horneri. Journal Fisheries China 9, 279-311.

Wedemeyer G.A. (1972) Some physiological consequences of handling stress in the juvenile coho salmon
(O. kisutch) and rainbow trout (S. gairdneri). Journal of Fish Research Board of Canada 29, 1780-1783.

Wijendra G.D.N.P. \& Pathiratne A. (2007) Evaluation of immune responses in an Indian carp, L. rohita (Ham.) fed with levamisole incorporated diet. Journal of Science of the University of Kelaniya 3, 17-28.

Yang X.L., Sun J.Y. \& Xu H.N. (1995) An experimental study on immunoregulatory effect of fucoidan. Chinese Journal of Marine Drugs, 14, 9-13.

Zhang Q.B., Yu P.Z., Zhou G.F., Li Z.E. \& Xu Z.H. (2003) Studies on antioxidant activities of fucoidan from Laminaria japonica. Chinese Traditional Herbal Drugs 34, 824-826. 